ASLI QoL 2017
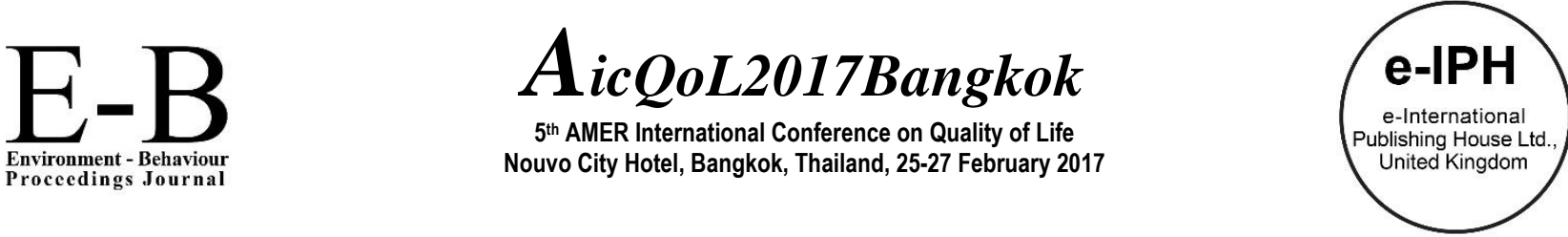

\title{
Increasing Tourism in Karo District, Indonesia Based on Place Identity
}

\author{
Nurlisa Ginting ${ }^{*}$, N. Vinky Rahman, Achmad Delianur Nasution \\ Department of Architecture, Faculty of Engineering, University of Sumatera Utara, 9 Dr. T. Mansur Street, Medan 20155, Indonesia
}

\begin{abstract}
Place identity is one of the necessary aspects to increase tourism. It can also improve someone's quality of life. This study aimed to find place identity on tourism development in Karo District, Indonesia, which can be used to create a tourism development program. This research used mix method by identified four elements: distinctiveness, continuity, self-esteem, and self-efficacy. The result shows that the strongest element of place identity was self-esteem and distinctiveness, while self-efficacy and continuity were weak. Furthermore, tourism in the area relatively goes well even though place identity elements were weak. However, the improvement to enhancing tourism is needed.
\end{abstract}

Keywords: Tourism Development; Place Identity; Karo District

ISSN: 2398-42870 2017. The Authors. Published for AMER ABRA by e-International Publishing House, Ltd., UK. This is an open access article under the CC BYNC-ND license (http://creativecommons.org/licenses/by-nc-nd/4.0/). Peer-review under responsibility of AMER (Association of Malaysian Environment-Behaviour Researchers), ABRA (Association of Behavioural Researchers on Asians) and cE-Bs (Centre for Environment-Behaviour Studies), Faculty of Architecture, Planning \& Surveying, UniversitiTeknologi MARA, Malaysia.

\subsection{Introduction}

Tourism is one of the leading economic generators of a country that its development can also increase the quality of life of both residents and tourists (Wang \& Xu, 2015). One of the essential things in developing tourism is tourist satisfaction; satisfied tourists will certainly return again (Ginting \& Wahid, 2015). Social interaction among residents and tourists give impact to tourist satisfaction (Wang $\& X u, 2015)$. The influence of the interaction can be good or bad depend on how the perception of the residents and tourists to tourism in that place (Sharpley, 2014).

Place-based perception is vital because tourism is a place-based phenomenon which it results involving place identity (Wang, 2016). Place identity in tourism area has been widely discussed (Ujang, 2012; Zakaria et al., 2015; Wang \& Xu, 2015). There are four aspects that form place identity, namely; distinctiveness, continuity, self-esteem, and self-efficacy (Twigger-Ross \& Uzzel, 1996). This research aims to investigate the perception of residents and tourists to place identity on tourism in Karo District. The result can be used to create a tourism development program in Karo District.

\footnotetext{
${ }^{*}$ Corresponding author. Tel.: +62811608102; fax: +62618219525 .

E-mail address:nurlisa@usu.ac.id
}

ISSN: 2398-42870 2017. The Authors. Published for AMER ABRA by e-International Publishing House, Ltd., UK. This is an open access article under the CC BYNC-ND license (http://creativecommons.org/licenses/by-nc-nd/4.0/). Peer-review under responsibility of AMER (Association of Malaysian Environment-Behaviour Researchers), ABRA (Association of Behavioural Researchers on Asians) and CE-Bs (Centre for Environment-Behaviour Studies), Faculty of Architecture, Planning \& Surveying, UniversitiTeknologi MARA, Malaysia.

DOI: http://dx.doi.org/10.21834/e-bpj.v2i5.62 


\subsection{Literature Review}

Place identity was formed by four aspects namely; continuity, self-esteem, self-efficacy, distinctiveness (Twigger-Ross \& Uzzell, 1996). The four aspects must be balanced to support place identity (Breakwell, 1993). Distinctiveness comes from someone' perception about the difference between one place to another (Berman, 2006). The particular character of one place makes a person has a special relationship with that place (Twigger-Ross \& Uzzell, 1996). The place that has the uniqueness will make that place easier to recognize than other places (Wang \& Xu, 2015). Landmark also plays a significant role in shaping distinctiveness. According to Lynch (1960), a landmark can distinguish one place from other places.

There are two forms of continuity, namely "place-referent continuity" \& "place of congruent continuity" (Twigger-Ross \& Uzzel, 1996). Place-referent continuity is a physical place that provides continuity on a person. Meanwhile, place-congruent continuity is the values of a place which gives a person their original identity. In continuity, the 'main' thing is not the physical form of a place but mainly the values contained in it, and someone' memories/experience (Ginting \& Wahid, 2015).

Self-esteem is when someone evaluates their self (Ginting \& Rahman, 2016). Self-esteem gives a sense of attachment to a person in a place and makes them commit to the development of that place (Lalli, 1992). According to Twigger-Ross et, al. (2003), a person would be happy with the place that has a visible symbol and gives them a sense of pride and will avoid a place that gives them the other way.

Self-efficacy is defined as someone' belief to their ability to control the environment (Wang \& Xu, 2015). Self-efficacy is "a manageable environment," where there are elements of comfort, safety, easy access, in the environment so that a person can do what they want to do (Twigger-Ross \& Uzzel, 1996). Self-efficacy can be formed when the environment can facilitate someone' lifestyle (Twigger-Ross, 2003). Based on the explanation above, researchers divided four aspects of place identity to some variables (see Table 1).

Table 1. Variable of Place Identity Principle

\begin{tabular}{llll}
\hline \multicolumn{1}{c}{ Distinctiveness } & \multicolumn{1}{c}{ Place Identity Principle } & \\
\hline$\bullet$ & Continuity & Self-Esteem \\
\hline$\bullet$ Landmark & $\bullet$ Value & $\bullet$ Evaluation & $\bullet$ Self-Efficacy \\
- Uniqueness & $\bullet$ Nostalgia/Memory & $\bullet$ Pride & $\bullet$ Comfort \\
$\bullet$ Different Perception & $\bullet$ Familiarity & $\bullet$ Attachment & $\bullet$ Safety \\
\hline
\end{tabular}

(Source: Author, 2016)

\subsection{Methodology}

\subsection{Research Area}

The research area is located in Karo District where it rich with its nature environment and cultural heritage. Karo District is also famous for its local products, such as fruit and vegetables. Unfortunately, this potential is still not well managed even though Karo District has many tourism destinations. In this research, the researcher only investigates five tourism destinations as samples. The location selected based on the pilot research conducted by Architecture students of the University of Sumatera Utara. They found that these five samples are the most familiar and attractive for residents and tourists. The sample sites namely: Pasar Buah; Bukit Gundaling; Sipiso Piso; Desa Lingga; And Bukit Kubu (see Fig. 1).

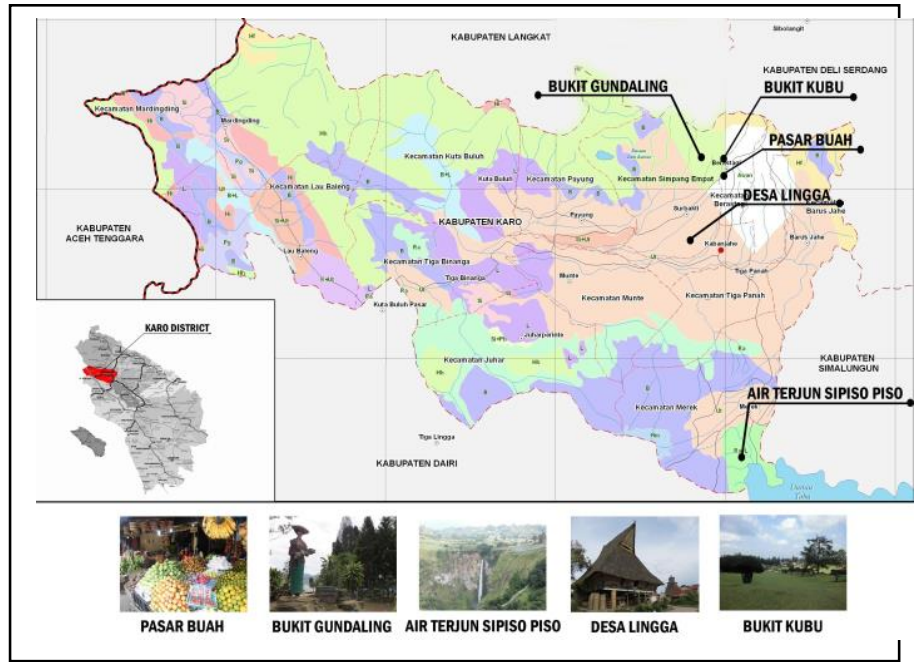

Fig. 1: Research Area

(Source: Google; Author, 2016) 


\subsection{Method}

This research used the combination of qualitative and quantitative methods. The qualitative method used eight depth interviews with tourism stakeholders such as academics; local figure; tourism practitioners; and government, and field observation was done to complete the qualitative data. While the quantitative method used the questionnaire distributed to 360 respondents to obtain their perception of place identity in the research area. Respondents involved were residents and tourists with the ratio of 50:50. There are four variables of distinctiveness, three variables of continuity, four variables of self-esteem, and four variables of self-efficacy to measure the place identity (see Table 1). The results of the questionnaire were processed statistically in SPSS 20 to obtain the overall mean of the perceptual items. Then, researchers combined the results of quantitative and qualitative data and triangulated it to create an overall conclusion about place identity of tourist destination in Karo District.

\subsection{Result and Discussion}

\subsection{Respondents}

360 questionnaires were distributed evenly, 72 respondents for each location. Respondents per site consist of 36 residents and 36 tourists (22 local tourists; 14 foreigner tourists). Out of 360 respondents, there are $53 \%$ male and $47 \%$ women. Most respondents had the range of age $25-49$ years old (46\%), followed by $18-24$ years old (36\%). $15 \%$ residents are not a native people and $97 \%$ local tourists are from outside Karo. While foreigner tourists mostly come from Asian (76\%) followed by European (21\%) and others (2\%). Residents' tourism-related jobs are majority a merchant $(85 \%)$ who mostly sells food and beverage (34\%). Most tourists travel with company, friends (44\%); Group (32\%); and family $(21 \%)$, only $4 \%$ of tourists travel alone. Their main reason to visit Karo District is mostly having sightseeing (59\%), followed by having a sight of traditional buildings (19\%) and shopping (7\%). Tourist visited Karo mostly only for one day or less (63\%). For $53 \%$ of tourists, It is their first time visited Karo.

\subsection{Distinctiveness}

Distinctiveness aspects are divided into four variables, namely landmark, uniqueness, the particular character, and different perception. Based on the results, response of respondents to overall distinctiveness variables were positive but not significant (3.18), Pasar Buah (residents 3.03; tourist 3.35); Bukit Gundaling (residents 3.04; tourist 3.28); Sipiso-Piso Waterfall (residents 3.07; tourist 3.22); Desa Lingga (residents 3.15; tourist 3.29); Bukit Kubu (residents 3.13; tourist 3.22) (Table 2).

Table 2. Respondents' perception of Distinctiveness Aspect in Research Area

\begin{tabular}{|c|c|c|c|c|c|c|c|c|c|c|c|c|}
\hline & \multirow{3}{*}{ Statements } & \multicolumn{2}{|c|}{ Pasar Buah } & \multicolumn{2}{|c|}{ Gundaling } & \multicolumn{2}{|c|}{ Sipiso-Piso } & \multicolumn{2}{|c|}{ Desa Lingga } & \multicolumn{2}{|c|}{ Bukit Kubu } & \multirow[b]{2}{*}{$\begin{array}{l}\overline{\widetilde{0}} \\
\stackrel{0}{\circ}\end{array}$} \\
\hline & & 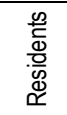 & $\begin{array}{l}\stackrel{\underline{m}}{\overline{5}} \\
\stackrel{0}{\circ}\end{array}$ & 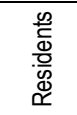 & $\begin{array}{l}\text { 苛 } \\
\text { 음 }\end{array}$ & 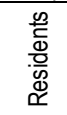 & 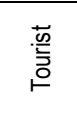 & 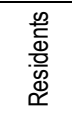 & $\begin{array}{l}\text { 해 } \\
\text { 흠 } \\
\vdash\end{array}$ & 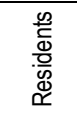 & 薃 & \\
\hline & & Mean & Mean & Mean & Mean & Mean & Mean & Mean & Mean & Mean & Mean & Mean \\
\hline \multirow{4}{*}{ LA } & I Can describe this place roughly & 2.86 & 2.94 & 2.52 & 3.03 & 3.03 & 2.97 & 3.13 & 3.06 & 2.94 & 3.00 & 2,95 \\
\hline & Landmark helps imagine this place & 3.31 & 3.28 & 3.08 & 3.53 & 3.19 & 3.22 & 2.94 & 3.31 & 3.22 & 3.39 & 3,25 \\
\hline & Landmark helps access/find this place & 3.33 & 3.42 & 3.08 & 3.58 & 3.25 & 3.44 & 3.00 & 3.31 & 3.08 & 3.50 & 3,30 \\
\hline & Access can be reached easily & 3.08 & 3.14 & 3.25 & 3.22 & 3.31 & 2.94 & 3.47 & 3.58 & 3.42 & 3.64 & 3,31 \\
\hline \multirow{3}{*}{ UN } & Has diversity of cultural activities & 3.00 & 3.31 & 2.80 & 3.33 & 2.86 & 3.22 & 3.02 & 3.08 & 3.03 & 2.94 & 3,23 \\
\hline & Has attractive cultural activities & 2.97 & 3.39 & 2.86 & 3.31 & 2.83 & 3.36 & 3.22 & 3.22 & 3.11 & 3.08 & 3,50 \\
\hline & Has diversity of local product & 3.03 & 3.56 & 3.16 & 3.17 & 3.14 & 3.36 & 3.27 & 3.06 & 2.92 & 3.22 & 2,92 \\
\hline \multirow{3}{*}{ PC } & Has attractive traditional buildings & 2.81 & 3.58 & 3.05 & 3.11 & 2.81 & 3.33 & 3.52 & 3.97 & 3.14 & 3.00 & 3,06 \\
\hline & I am attracted by this place & 3.03 & 3.75 & 3.27 & 3.47 & 3.64 & 3.36 & 3.52 & 3.97 & 3.31 & 3.67 & 3,14 \\
\hline & Has an attractive local transportation & 3.03 & 3.47 & 3.38 & 3.31 & 2.47 & 3.00 & 2.13 & 2.14 & 3.11 & 3.11 & 3,19 \\
\hline \multirow{3}{*}{$\mathrm{DP}$} & The cultural activity is different from other & 3.00 & 3.33 & 2.97 & 3.25 & 2.97 & 3.42 & 3.08 & 3.33 & 3.11 & 2.86 & 3,13 \\
\hline & No place is comparable & 2.92 & 3.00 & 3.08 & 3.11 & 3.39 & 3.06 & 3.50 & 3.42 & 3.22 & 3.19 & 3,19 \\
\hline & \multicolumn{5}{|c|}{$\mathrm{LA}=$ Landmark UN = Uniqueness $\mathrm{PC}=$ Particular Character $\mathrm{DP}=$ Different Perception } & Val & $1=$ stro & ly disag & $5=s$ & ngly agr & & 3,18 \\
\hline
\end{tabular}

(Source: Author, 2016)

Landmark is a reference point and conspicuous object (Ginting et al., 2016). To find their way, tourists see landmark as a mark in three-dimensional composition (Hussain \& Ujang, 2014). The results indicate that most respondents could not portray the place where is being visited roughly (2.95). The inability of respondents in describing study areas shows that study areas are not different from the other places because one of the characteristics of the distinct area is imageable or easily described (Lynch, 1960). However, the majority of respondents agreed that as a landmark, study area helped them in imagined (3.25) and accessed (3.30) Karo District. Also, landmark helps a person oriented and access a place (Hussain \& Ujang, 2014). Moreover, access to study area according to the respondents is quite easy to access (3.31).

A place that has uniqueness would be easy to remember and describe (Ginting et al., 2016). According to respondents, cultural activities in the study area are diverse (3.06) and interesting (3.14), and local products are distinct (3.19). In the study area, Pasar Buah has the best appraisement from respondents (see Table 2). It is because the cultural event often held at Pasar Buah. However, unfortunately, these activities are not done periodically and scheduled. Governments should plan cultural events regularly and scheduled. Events tend attracted most tourists to experience a particular culture that expresses their cultural identity and distinguish it with another culture (Chin et al., 2014; Ujang et al., 2015). Furthermore, Pasar Buah is also a favorite souvenir place for tourists. 
Products offered in Pasar Buah are varied from fruit, vegetables, flowers, clothes, souvenirs, trinkets, decoration and other. Local product shows the distinct characteristics of place and a mark for tourists that they have visited the place (Kastenholz, 2016).

The particular character of tourism area can give benefit and balanced to that place (Marpaung, 2016). Based on the questionnaire, the study area is considered attractive by respondents (3.50). Sipiso-Piso Waterfall (residents3.64; tourist 3.36) and Desa Lingga (residents3.52; tourist 3.97) are the most interesting according to respondents. High appraisement of respondents is because most of them are interested in the natural panorama of Sipiso-Piso Waterfalls and Karo culture of Desa Lingga. Respondents also agreed that traditional houses in study area are interesting (3.23), especially in Desa Lingga (residents 3.52; tourist 3.97), one of the villages in Karo that still have Karo traditional house. This finding is in line with Dupeyras' finding (2013), tourism experience is about connecting someone with place identity, especially the nature, culture, and way of life. The majority of respondents perceived local transportation like riding a horse or horse cart was not attractive (2.92). Respondents are disappointed with horses' excrement that scattered along the way, especially in Pasar Buah. While cleanliness is one of environment quality that influences tourist's revisiting intention and satisfaction (Sadat et al., 2016)

The perception that a place is different with other place is one of the factors that make a place have distinctiveness (Berman, 2006). There is a significant difference opinion between residents and tourists. According to residents, cultural activities in study area were not much different from other places, but according to tourists, cultural activities in study area were quite different from other places (3.13) (see Table 2), except in Bukit Kubu it is otherwise (residents 3.11; tourist 2.86). Residents argue that cultural activities in the study area were seldom so it cannot be compared to other places. Most respondents agreed that the study area was not comparable to other places $(3,19)$, only Pasar Buah (residents 2.92; tourist 3.00) that according to respondents is similar to other places. The low assessment is because most respondents see Pasar Buah merely as a place to shopping like any other places. It is also expressed by the key respondent.

"Pasar Buah is always visited by tourists to buy souvenirs, but it is not different with others market in general. If it built with Karo architecture, it could give uniqueness on Pasar Buah." Key Respondent: Travel Association)

\subsection{Continuity}

There are three variables of continuity aspect, value, nostalgia/memory, and familiarity. The response of respondents to continuity aspect in the study area was quite low (3.14) (see Table 3). Tourists were more inclined to visit the culture elements of other countries to gain knowledge and experience (Samsudin, 2015). Respondents were slightly interested in cultural activities in the study area (3.15). The majority of respondents were also interested in history of the study area (3.25). Respondents were also interested in seeing the traditional houses in the study area (3.24). Desa Lingga (see Table 3) has the highest assessment in these three statements. It is because Desa Lingga is the only study area that has a long history and traditional houses. According to respondents, study area was a place which quite popular with its traditional houses (3.15), only in Pasar Buah (residents2.61; tourist 3.36) and Sipiso-Piso Waterfall (residents2.64; tourist 3.22), respondents were less agreed. It is because both locations only provide natural scenery and marketing activities.

Table 3. Respondents' perception of Continuity Aspect in Research Area

\begin{tabular}{|c|c|c|c|c|c|c|c|c|c|c|c|c|}
\hline & \multirow{3}{*}{ Statements } & \multicolumn{2}{|c|}{ Pasar Buah } & \multicolumn{2}{|c|}{ Gundaling } & \multicolumn{2}{|c|}{ Sipiso-Piso } & \multicolumn{2}{|c|}{ Desa Lingga } & \multicolumn{2}{|c|}{ Bukit Kubu } & \multirow[b]{2}{*}{$\begin{array}{l}\text { 要 } \\
\text { [0 }\end{array}$} \\
\hline & & 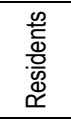 & 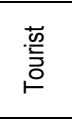 & 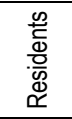 & $\begin{array}{l}\text { 藃 } \\
\text { 言 }\end{array}$ & 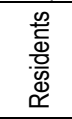 & $\begin{array}{l}\stackrel{\bar{m}}{\bar{y}} \\
\stackrel{0}{\circ}\end{array}$ & 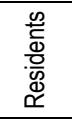 & $\begin{array}{l}\text { 蒿 } \\
\text { 产 }\end{array}$ & 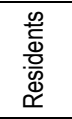 & $\begin{array}{l}\text { 㚸 } \\
\text { 产 }\end{array}$ & \\
\hline & & Mean & Mean & Mean & Mean & Mean & Mean & Mean & Mean & Mean & Mean & Mean \\
\hline \multirow{5}{*}{ VA } & I am interested in culture activities & 3.11 & 3.28 & 2.88 & 3.17 & 2,86 & 3,28 & 3,13 & 3,36 & 3,11 & 3,31 & 3,15 \\
\hline & I am impressed with the historical story & 2.81 & 3.28 & 3.13 & 3.28 & 2,94 & 3,11 & 3,58 & 3,83 & 3,31 & 3,19 & 3,25 \\
\hline & I am interested to see traditional house & 2.94 & 3.31 & 2.88 & 3.36 & 2,67 & 3,36 & 3,47 & 3,94 & 3,33 & 3,14 & 3,24 \\
\hline & Famous with its traditional hose & 2.61 & 3.36 & 2.88 & 3.11 & 2,64 & 3,22 & 3,69 & 3,86 & 3,25 & 2,86 & 3,15 \\
\hline & My hometown & 3.03 & 2.59 & 3.00 & 2.14 & 2,72 & 2,36 & 3,69 & 1,95 & 3,28 & 2,27 & 2,80 \\
\hline \multirow{3}{*}{$\mathrm{N} / \mathrm{M}$} & Remind me of my childhood & 2.92 & 2.86 & 3.08 & 2.32 & 2,81 & 2,41 & 3,61 & 1,95 & 3,19 & 2,50 & 2,83 \\
\hline & I have a memorable experience & 3.14 & 3.50 & 3.11 & 3.33 & 3,17 & 3,11 & 3,58 & 2,83 & 3,53 & 3,06 & 3,24 \\
\hline & I will visti/stay in this place in the future & 3.25 & 3.50 & 3.00 & 3.36 & 3,14 & 2,67 & 3,30 & 3,61 & 3,36 & 3,64 & 3,28 \\
\hline \multirow{6}{*}{ FA } & Good facilities & 2.78 & 2.86 & 2.61 & 2.53 & 2,67 & 2,81 & 2,66 & 2,42 & 3,22 & 3,36 & 2,79 \\
\hline & Lodging around this place is well maintained & 3.06 & 3.08 & 3.13 & 3.03 & 2,64 & 2,94 & 2,36 & 2,86 & 3,36 & 3,47 & 2,99 \\
\hline & I am intersted in panormane & 3.28 & 3.47 & 3.36 & 3.61 & 3,50 & 3,56 & 3,16 & 3,56 & 3,53 & 3,69 & 3,47 \\
\hline & I am impressed with the local wisdom & 3.17 & 3.25 & 3.13 & 3.17 & 3,17 & 3,31 & 3,50 & 3,97 & 3,33 & 3,72 & 3,37 \\
\hline & Residents are friendly & 3.33 & 3.53 & 3.33 & 3.44 & 3,39 & 3,14 & 3,83 & 4,11 & 3,53 & 3,67 & 3,53 \\
\hline & \multicolumn{3}{|c|}{ VA $=$ Value $N / M=$ Nostalgia/Memory FA = Familiarity } & Value & Eormat & $=$ stron & y disagr & $5=\mathrm{st}$ & ingly ag & & & 3,16 \\
\hline
\end{tabular}

(Source: Author, 2016)

Memory is a sign of the relationship between a person and a place (Ujang, 2012). The study area is the homeland for almost all residents but not with tourists (2.8). Likewise, only a few respondents recalled their childhood in study area (2.83). Tourists will return to one place based on their experience (Cheshmenzagi et al., 2012). Most respondents had good enough experience in study area (3.2), and they also want to visit again/stay in the future (3.28). However, unfortunately, in Sipiso-Piso Waterfall, most of the tourist (2.67) didn't want to come back again. It is because when they climb down to the waterfall, they felt exhausted, and give them bad experience. 
Familiarity is when someone associated with a place and its facility through an activity (Ujang \& Zakaria, 2015). The existing facilities in study area were considered quite poor by respondents (2.79). The place with great facilities, attractive, functional, clean and not polluted became a major tourist destination (Samsudin, 2015). Unfortunately, public facilities in study area are not wellmaintained. Only Bukit Kubu that have good facilities (residents 3.22; tourist 3.36), because Bukit Kubu has employee that periodically maintained it. Lodging/Hotel around location was considered good enough by respondents (2.99). Only in Desa Lingga (residents 2.33; tourist 2.86) and Sipiso-Piso Waterfall (residents 2.64; tourist 2.94) that has a poor assessment from respondents. It is because around Desa Lingga and Sipiso-Piso Waterfall there is no lodging or hotel. However, overall, Hotel in Karo District is quite satisfying. It is also supported by key respondents:

\section{"I think regarding accommodation, in North Sumatra, Karo is the most prepared."(Key Respondent: BAPPEDA Karo District)}

The majority of respondents was fascinated by nature panorama in study area (3.47), each location provides a natural panorama that can be enjoyed by visitors (see Table 3). Acceptance of residents for tourists can improve tourist' satisfaction (Basnezhin, 2015). The average of respondents was also impressed with the local wisdom in the study area (3.37). According to respondents, residents are friendly to tourists (3.53), especially in Desa Lingga (residents 3.83; tourist 4.11). It is because they are used to serve tourists. It is also supported by key respondents:

"Residents in Desa Lingga are expert in serving tourists, introducing traditional house as well as its history and culture." (Key Respondent: Local Figure)

\subsection{Self-Esteem}

The response of respondents to self-esteem aspect in the study area was considered quite good (3.22) (see Table 4). The quality of facilities will build a long-term relationship with tourists and make them loyal to that place (Basnezhin, 2015). Unfortunately, some respondents perceived that it was hard to find a toilet (2.77), information center (2.85) and place to eat (3.04). Bukit Kubu is the only place that receives good assessment (see Table 4). It is because public facilities in Bukit Kubu are adequate and well-maintained. Meanwhile, most respondents agreed that to find lodging around the study area is quite easy (3.08). Also, they are agreed that it cost was affordable (3.05). Likewise, the price of goods and food/drink in study area were quite affordable (3.11) \& (3.13).

Table 4. Respondents' perception of Self Esteem Aspect in Research Area

\begin{tabular}{|c|c|c|c|c|c|c|c|c|c|c|c|c|}
\hline & \multirow{3}{*}{ Statements } & \multicolumn{2}{|c|}{ Pasar Buah } & \multicolumn{2}{|c|}{ Gundaling } & \multicolumn{2}{|c|}{ Sipiso-Piso } & \multicolumn{2}{|c|}{ Desa Lingga } & \multicolumn{2}{|c|}{ Bukit Kubu } & \multirow[b]{2}{*}{$\begin{array}{l}\bar{\pi} \\
\text { ㅁㅁ }\end{array}$} \\
\hline & & 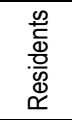 & 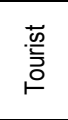 & 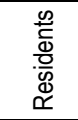 & $\begin{array}{l}\text { 馬 } \\
\text { 흠 }\end{array}$ & 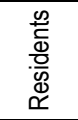 & 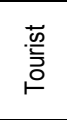 & 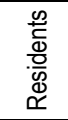 & 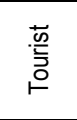 & 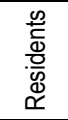 & 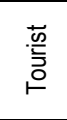 & \\
\hline & & Mean & Mean & Mean & Mean & Mean & Mean & Mean & Mean & Mean & Mean & Mean \\
\hline \multirow{7}{*}{ EV } & Easy to find a public toilet & 2,64 & 2,94 & 2,88 & 2,39 & 3,00 & 2,72 & 2,33 & 2,39 & 3,11 & 3,28 & 2,77 \\
\hline & Easy to find the information center & 2,86 & 2,72 & 2,97 & 2,67 & 2,69 & 2,72 & 2,36 & 3,00 & 3,25 & 3,25 & 2,85 \\
\hline & Easy to find a hotel/lodge & 3,11 & 3,33 & 3,16 & 3,25 & 2,78 & 3,08 & 2,36 & 2,69 & 3,47 & 3,58 & 3,08 \\
\hline & Easy to find a restaurant & 3,11 & 3,33 & 2,94 & 2,92 & 2,75 & 2,97 & 2,69 & 2,92 & 3,25 & 3,56 & 3,04 \\
\hline & Hotel/lodging around is affordable & 3,00 & 3,31 & 2,86 & 3,11 & 2,78 & 3,08 & 2,66 & 3,08 & 3,31 & 3,28 & 3,05 \\
\hline & Goods cost is affordable & 2,83 & 3,28 & 3,02 & 3,11 & 3,19 & 3,14 & 2,86 & 3,22 & 3,25 & 3,19 & 3,11 \\
\hline & Food/beverages costs is affordable & 2,78 & 3,33 & 2,97 & 3,19 & 3,14 & 3,08 & 2,97 & 3,17 & 3,33 & 3,33 & 3,13 \\
\hline \multirow{2}{*}{ PR } & Has high historical value & 3,06 & 3,33 & 3,25 & 3,31 & 3,19 & 3,44 & 3,47 & 3,72 & 3,33 & 3,53 & 3,36 \\
\hline & Has symbol characteristic & 3,06 & 3,61 & 2,91 & 3,42 & 3,28 & 3,33 & 3,44 & 3,58 & 3,22 & 3,53 & 3,34 \\
\hline \multirow{7}{*}{ AT } & I am part of this place & 3,25 & 2,94 & 3,16 & 2,83 & 3,44 & 3,11 & 3,61 & 2,53 & 3,39 & 3,36 & 3,16 \\
\hline & This place is important for me & 3,14 & 3,14 & 3,22 & 2,72 & 3,25 & 3,03 & 3,55 & 2,86 & 3,56 & 3,44 & 3,19 \\
\hline & This place says a lot about me & 3,03 & 2,81 & 3,02 & 2,39 & 3,22 & 2,86 & 3,47 & 2,36 & 3,33 & 3,06 & 2,96 \\
\hline & I feel happy & 3,22 & 3,36 & 3,33 & 3,25 & 3,31 & 3,39 & 3,55 & 3,39 & 3,56 & 3,89 & 3,43 \\
\hline & I feel connected & 3,28 & 3,08 & 3,19 & 2,89 & 3,28 & 3,06 & 3,5 & 2,81 & 3,69 & 3,50 & 3,23 \\
\hline & I feel sad if characteristic of this place is gone & 3,47 & 3,75 & 3,58 & 3,58 & 3,47 & 3,53 & 3,86 & 4,06 & 3,86 & 4,03 & 3,72 \\
\hline & I feel very sad if this place is gone & 3,39 & 3,75 & 3,63 & 3,58 & 3,50 & 3,58 & 3,88 & 4,06 & 4,03 & 4,19 & 3,76 \\
\hline \multirow{3}{*}{$\mathrm{CO}$} & If I can, I would like to spend more time & 3,19 & 3,56 & 3,33 & 3,31 & 3,31 & 3,28 & 3,38 & 3,39 & 3,64 & 3,75 & 3,41 \\
\hline & I will contributed for developing this place & 3,00 & 3,17 & 3,38 & 3,11 & 3,47 & 3,36 & 3,61 & 3,25 & 3,53 & 3,94 & 3,38 \\
\hline & $\mathrm{EV}=$ Evaluation $\mathrm{PR}=$ Pride $\mathrm{AT}=$ Attachmen & $=$ Com & itment & \multicolumn{8}{|c|}{ Value Format: $1=$ strongly disagree, $5=$ strongly agree } & 3,22 \\
\hline
\end{tabular}

Symbols \& history of culture increase feelings tied to a place (Shabek, 2015). The majority of respondents are proud of history in study area (3.36). They are also proud of the symbols features in study area (3.34). Desa Lingga (see Table 4) gets the highest assessment because it has rich history and physical characteristics peculiar to Karo culture.

Functional and emotional ties are important in forming place identity (Ujang, 2012). Most Respondents felt that they part of study area (3.16). They have also felt that it was an important place (3.19). Respondents also felt happy (3.43) and connected with study area (3.23). On the other hand, the study area did not speak about them (2.96). Place attachment is essential to make place to be successful (Shabek, 2015). Respondents felt sad if characteristic of study area were gone (3.72), especially in Desa Lingga. It is 
because of history value in Desa Lingga that no other places owned it. Furthermore, respondents also feel sad if study area were destroyed (3.76). It is also supported by one of the key respondents.

"In 1970, there are 29 traditional houses. Now only four remaining, Gerga, Belang Ayo, Griten, and Sapo Ganjang. It is so unfortunate." (Key Respondent: Academic Figure).

If they could, respondents would like to spend more time in study area (3.41). They also would like to contribute to the development of the study area (3.38). A person who has high self-esteem to place tends to be more committed than those who have low selfesteem (Bankone \& Ajadune, 2014).

\subsection{Self-Efficacy}

The result shows that self-efficacy in study area are still low (3.16) (see Table 5). Out of four variables of self-efficacy, none gets positive assessment. Respondents were unsatisfied with study area, only $37 \%$ of tourist stay more than one day. The environment that provides confidence to a person will also give sense of self-efficacy on that person (Twigger-Ross \& Uzzel, 1996). The majority of respondents felt satisfied with study area (3.36). Respondents agreed that they could do their activities (3.28). However, that place is not the best place to do the things they want (3.08). On the other hand, according to respondents the study area provides new insights and experiences (3.37) and gives positive information (3.24) to them. They are also wanted to recommend the study area to others (3.49). The existence of the information center in the tourism help tourists to know the things that they do not know, and help them to understand about the place (Ginting, 2016). Unfortunately, most respondents considered that the information center is still not available in study area (2.95). Even though in study area already have an information center, but the condition is not well maintained.

Table 5. Respondents' perception of Self-Efficacy Aspect in Research Area

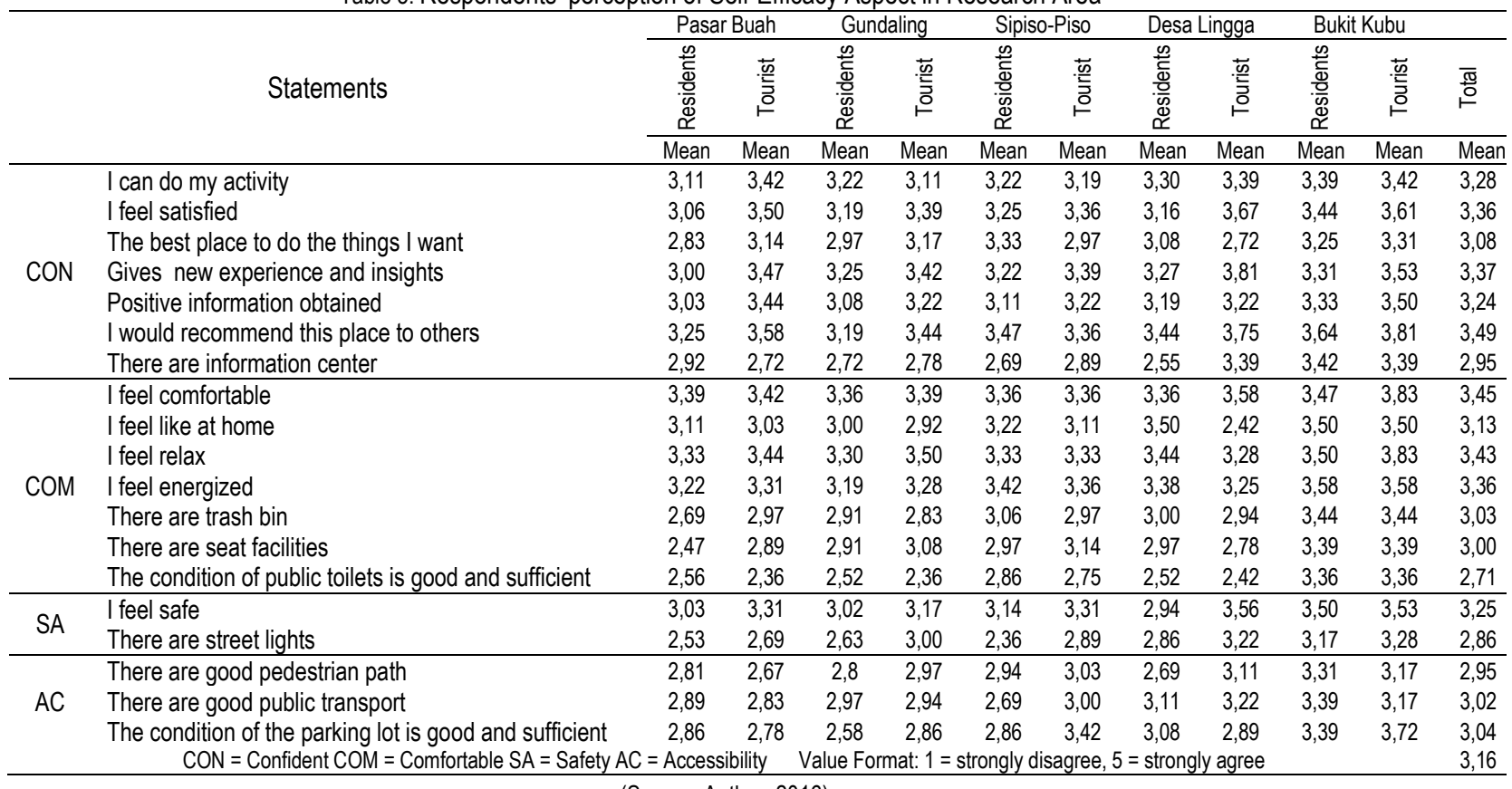

(Source: Author, 2016)

A person who feels comfortable will be able to do their work (Twigger-Ross \& Uzzell, 1996). Most respondents feel comfortable (3.45), relax (3.43), and energized (3.36) in the study area. Some respondents also felt like at home in the study area (3.13). However, supporting facilities such as a trash bin, seating place and toilet in study area were still not satisfying. Most respondents agreed that trash bins in study area were bad (3.03), like in Pasar Buah and Bukit Gundaling, there's still a lot scattered dirt horses. A clean environment can make a place more attractive (Zakaria \& Ujang, 2015). Therefore the improvement of cleanliness in study area is needed. Moreover, seats in study area, according to respondents were still insufficient (3.00). Respondents perceived that it is difficult to find a place to sit down for a moment. The seat is one of the important things to improve comfort and quality of life of a person (Ja'far et al., 2012). Furthermore, one of comfort determinant in a place is public toilet(Ja'far et al. 2012). Unfortunately, most respondents argue that the condition of toilets in study area not adequate (2.71). It is also supported by key respondents.

"If we go to toilet before we eat, we will lose our appetite. Each place should build a restroom, and it is okay to have pay for it if it is always well-maintained." (Key Respondent: Travel Association)

The safety will influence tourists' decision to go to a place where they tried to avoid all dangerous events such as crime (Amir et al., 2015). Most respondents felt secure in the study area (3.25). They perceived that the crime level in Karo District is minimal. 
Unfortunately, the lighting in the study area is still inadequate (2.86), and it makes many tourists left early even though they still want to spend more time. While, the lighting gives a feeling safe to someone (Mohaved et al., 2012).

A good pedestrian path can increase tourism activities (Zakaria et al., 2014). However, pedestrian path in study area, according to the respondents still not good (2.95). Pedestrian path in the study area was difficult to find, besides the condition was poor and not well maintained. Public transportation according to respondents also still not satisfying (3.02). It is because public transportation in the study area was still insufficient, especially in Sipiso-Piso Waterfall and Desa Lingga. Public transportation facilities must be improved because public transportation is one of the essential things to developed tourism (Amir et al., 2015).

The availability of the parking area can affect the tourists' desire to return again to a place (Snider et al., 2015). Nonetheless, the parking area in the study area has low assessment from respondents (3.04). The parking area in study area was still not clear and insufficient. Only in Sipiso-Piso Waterfalls (residents 2.86; tourist 3.42) and Bukit Kubu (residents3.39; tourist 3.72) that received a positive response. The positive response obtained because parking area in there is clear and adequate, but in the Sipiso-Piso Waterfall when there are many tourists come, parking area was not organized, so it still needs to be improved.

\subsection{Conclusion}

The result shows that the strongest elements of place identity in study area are self-esteem and distinctiveness, while self-efficacy and continuity were weak. Furthermore, overall finding indicates that distinctiveness, continuity, self-esteem, self-efficacy, has not yet satisfactory. The low perception of respondents to place identity affects tourists' stayed in Karo. Although the numbers of tourists who come quite a lot, they have only stayed for one day or less. Increasing place identity in Karo tourism area will increasing its tourism. According to Wang \& Xu (2015), promoting place identity will attract tourists and improve its competitiveness. Therefore, if place identity in Karo tourism area is not improved, Karo District would be left behind from other tourism areas.

The government, residents and related parties need to work together to improve the tourist area in Karo based on place identity. (1) In distinctiveness aspect, uniqueness, particular character, and different perception still need to be developed; (2) while in continuity aspect, the values of the culture \& history of Karo should be maintained, and positive experience and familiarity with the facilities need to be increased; (3) physical quality evaluation in tourism area needs to be improved, to enhance self-esteem; and (4) Facilities that affect the comfort, confidence, safety and accessibility still need to be improved, to increased self-efficacy. Detailed and comprehensive improvement requires a strategy and a clear guide and planned.

It is recommended to investigating on how to improve place identity of tourism destinations in Karo District to complete the current research. Researchers also suggested further research on place identity in others tourism destinations. As each tourist destinations has different place identity (Wang \& Xu, 2015).

\section{Acknowledgment}

This research is funded by Ministry of Education and Culture of Indonesia. Also, we would like to thank all students of Department of Architecture, Faculty of Engineering, University of Sumatera Utara, for their support.

\section{References}

Amir, A. F., Ismail, M. N. I., \& See, T. P. (2015). Sustainable Tourist Environment: Perception of International Women Travelers on Safety and Security in Kuala Lumpur. Procedia-Social and Behavioral Sciences, 168, 123-133.

Amir, S., Osman, M. M., Bachok, S., \& Ibrahim, M. (2016). Local economic benefit in shopping and transportation: a study on tourists' expenditure in Melaka Malaysia. Procedia-Social and Behavioral Sciences, 222, 374-381.

Bankone, Emmanuel Tamitope \& Ajagun, Olufunmi Victoria (2014). Psychological Contract and Organizational Based Self Esteem as Antecedents of Organizational Commitment among Government Workers in Ekiti State, Nigeria. International Journal of Research in Humanities and Social Studies, 1, 24-33

Bazneshin, S. D., Hosseini, S. B., \& Azeri, A. R. K. (2015). The Physical Variables of Tourist Areas to Increase the Tourists' Satisfaction Regarding the Sustainable Tourism Criteria: Case Study of Rudsar Villages, Sefidab in Rahim Abad. Procedia-Social and Behavioral Sciences, 201, 128-135.

Berman, R. W. (2006). Assesing Urban Design: Historical Ambience on The Waterfront. UK: Lexington Books.

Breakwell, G. M. (1993). Identity Process Theory: Identity, Social Action and Social Change.Cambridge University Press.

Cheshmehzangi, A., \& Heat, T. (2012). Urban identities: Influences on socio-environmental values and spatial inter-relations. Procedia-Social and Behavioral Sciences, 36, 253-264.

Chin, C.-H , Hussain, K., Kahl, C., Poulain, J. P., Ragavan, N. A., Nair, V. (2014). Rural Tourism Destination Competitiveness: A Study on Annah Rais Longhouse Homestay, Sarawak. Procedia - Social and Behavioral Sciences, 144, 35-44.

Dupeyras, A., \& MacCallum, N. (2013). Indicators for Measuring Competitiveness in Tourism: OECD Publishing.

Ginting, N. (2016). How Self-efficacy Enhance Heritage Tourism in Medan Historical Corridor, Indonesia. Procedia-Social and Behavioral Sciences, 234, 193-200. 
Ginting, N., \& Rahman, N. V. (2016). Maimoon Palace Heritage District in Medan, Indonesia: What We Preserve and Why We Preserve?. Procedia-Social and Behavioral Sciences, 222, 332-341.

Ginting, N., Rahman, N. V., Nasution, A. D., (2016). More Attractive More Identified : Distinictiveness in Embedding Place Identity. Proceeding IEREK International Conference on Green Urbanism.

Ginting, N., \& Wahid, J. (2015). Exploring Identity's Aspect of Continuity of Urban Heritage Tourism. Procedia-Social and Behavioral Sciences, 202, 234-241.

Harun, N. Z., Zakariya, K., Mansor, M., \& Zakaria, K. (2014). Determining attributes of urban plaza for social sustainability. Procedia-Social and Behavioral Sciences, 153, 606-615.

Hussain, K. A. M., \& Ujang, N. (2014). Visitors' identification of landmarks in the historic district of Banda Hilir, Melaka, Malaysia. Procedia-Social and Behavioral Sciences, 153, 689-699.

Ja'afar, N.H., Sulaiman, A.B., Shamsuddin, S. (2012). The contribution of landscape features on traditional streets in Malaysia. Procedia-Social and Behavioural Sciences, 50, 643-656.

Kastenholz, E., Eusébio, C., \& Carneiro, M. J. (2016). Purchase of local products within the rural tourist experience context. Tourism Economics, 22(4), 729-748.

Lalli, Marco. (1992). Urban-Related Identity: Theory, Measurement, And Empirical Findings. Journal of Environmental Psychology, 12, 285-303

Lynch,K.(1960). The Image of the City, Cambridge, The MIT Press.

Marpaung, B. O. (2016). Communication Strategy Planning of Fisherman Kampung Medan Belawan as a Tourist Destination. Procedia-Social and Behavioral Sciences, 234, 344-352.

Movahed, S., Azad, S. P., \&Zakeri, H. (2012). A Safe Pedestrian Walkway; Creation a Safe Public Space Based on Pedestrian Safety. Procedia-Social and Behavioral Sciences, 35, 572-585.

Sadat, M. M., \& Chang, L. H. (2016). The Impact of Environmental Quality of Revisiting Intention. Journal of Quality Assurance in Hospitality \& Tourism,17(2), 209-223.

Samsudin, P. Y., \& Maliki, N. Z. (2015). Preserving Cultural Landscape in Homestay Programme Towards Sustainable Tourism: Brief Critical Review Concept. Procedia-Social and Behavioral Sciences, 170, 433-441.

Shabak, M., Norouzi, N., Abdullah, A. M., \& Khan, T. H. (2015). Children's Sense of Attachment to the Residential Common Open Space. Procedia-Social and Behavioral Sciences, 201, 39-48.

Sharpley, R. (2014). Host perceptions of tourism: A review of the research. Tourism Management, 42, 37-49.

Snider, A., Luo, S., Hill, J., \& Herstine, J. (2015). Perceptions of availability of beach parking and access as predictors of coastal tourism. Ocean \& Coastal Management, 105, 48-55.

Twigger-Ross, C. L., \& Uzzell, D. L. (1996). Place and identity processes.Journal of environmental psychology, 16(3), 205-220.

Twigger-Ross, CL, Bonaiuto M Breawell. G. M (2003). Identity Theories and enviromental Psychology. In, M. Bonnes. T. Lee \& Enviromental Issues ( pp 203-234). Aldershot, UK, Ashgate Publishing.

Ujang, N., \& Zakariya, K. (2015). Place Attachment and the Value of Place in the Life of the Users. Procedia-Social and Behavioral Sciences, 168, 373-380.

Ujang, N. (2012). Place attachment and continuity of urban place identity.Procedia-Social and Behavioral Sciences, 49, 156-167.

Wang, S. (2016). Roles of place identity distinctiveness and continuity on resident attitude toward tourism. European Journal of Tourism Research, 13, 58.

Wang, S., \& Xu, H. (2015). Influence of place-based senses of distinctiveness, continuity, self-esteem and self-efficacy on residents' attitudes toward tourism. Tourism Management, 47, 241-250.

Zakariya, K. Harun, N. Z., and Mansor, M. (2015). Place Meaning of the Historic Square as Tourism Attraction and Community Leisure Space. Procedia - Social and Behavioral Sciences,202, $477-486$

Zakaria, J., \& Ujang, N. (2015). Comfort of walking in the city center of Kuala Lumpur. Procedia-Social and Behavioral Sciences, 170, 642-652. 